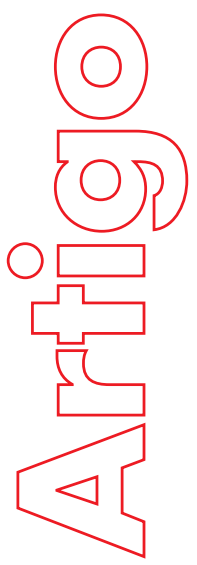

revista

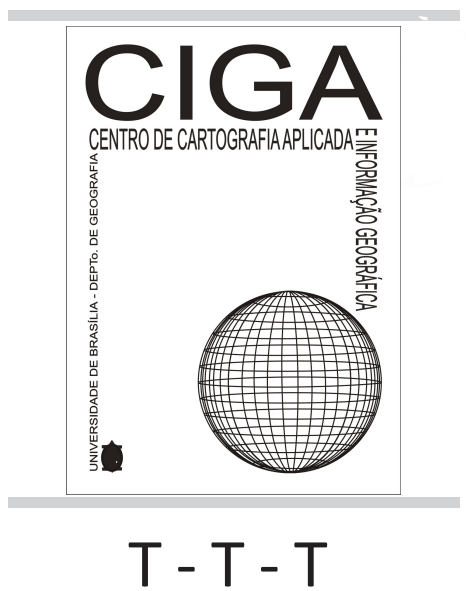

Revista Eletrônica:

Tempo - Técnica - Território,

V.5, N.2 (2014), 41:57

ISSN : 2177-4366

DOI: https://

doi.org/10.26512/

ciga.v5i2.15400

\section{CONTEMPORARY QUILOMBOS AND BIODIVERSITY PROTECTION: A THEORETICAL CONCEPTUAL APPROACH}

\section{RODRIGO DE OLIVEIRA VILELA NEIO LUCIO DE OLIVEIRA CAMPOS}

p. $41-57$

Como citar este artigo:

VILELA, R. O., Neio Lucio de Oliveira Campos. CONTEMPORARY QUILOMBOS AND BIODIVERSITY PROTECTION: A THEORETICAL CONCEPTUAL APPROACH. Eletronic Magazine: Time - Techinique Territorry, v.5, n.2 (2014), p. 41:57 ISSN: 2177-4366.

DOI: https://doi.org/10.26512/ciga.v5i2.15400

Available in: http://periodicos.unb.br/index.php/ciga/

Este obra está licenciado com uma Licença Crea tive Commons Atribuição-NãoComer cial 4.0 Inter nacional. 


\title{
CONTEMPORARY QUILOMBOS AND BIODIVERSITY PROTECTION: \\ A THEORETICAL CONCEPTUAL APPROACH
}

\author{
RODRIGO DE OLIVEIRA VILELA
}

Geographer, Master in Geography at Postgraduate Program in Geography at the University of Brasilia (UNB). E-mail: geographo@gmail.com

\section{NEIO LUCIO DE OLIVEIRA CAMPOS}

Geographer, Ph.D. in Urban and Regional Planning - Federal University of Rio de Janeiro (UFRJ). Professor of the Department of Geography - University of Brasilia. Director of the Center for Excellence in Tourism - CET/UNB.

E-mail: neiocamp@unb.br

\section{Tradução para o Inglês: Cleison Leite Ferreira}

\begin{abstract}
Quilombos were and still are structures that go beyond the typical feature of resistance. These communities are materializations of African social organization that was formed in Brazilian urban and rural areas. An important aspect of the presence of people of African origin in the Brazilian territory concerns the relationship between the quilombola communities and the environment that surrounds them. The management of natural resources in the catchment area of the community has always been a concern of traditional populations. Indeed, the need to use these resources in a sustainable way is an important strategy in the maintenance and reproduction of the community throughout their generations. We share the principle that biodiversity, as currently perceived, is a result of the relationship between nature and action of society and of human cultures. Thus, it is also a cultural and social construction. In this paper, we present the still dominant model of conservation, called preservationism, and also that model that considers the conservation of biodiversity in line with traditional societies, conservationism or social ecology. It is in the question discussed above we emphasize the need for a paradigm shift in biodiversity protection. We are not ruling out the need for environmental conservation, which is essential for the reproduction of human life, only pointing out the greater vulnerability of traditional communities; face the transformations of the modern world.
\end{abstract}

RESUMO: Os quilombos foram e são estruturas que vão além da sua típica característica de resistência, essas comunidades são materializações da organização social africana que se constituiu nos espaços urbanos e rurais brasileiros. Um ponto importante, da presença de população de matriz africana no território brasileiro, diz respeito à relação das comunidades quilombolas com o meio ambiente que as cercam. $\mathrm{O}$ manejo dos recursos naturais existentes na área de abrangência da comunidade sempre foi uma preocupação das populações tradicionais. Na verdade, a necessidade de utilizar esses recursos de modo sustentável é estratégia importante na manutenção e reprodução da comunidade ao longo de suas gerações. Partilhamos do princípio de que a Biodiversidade, tal qual percebemos atualmente, é um resultado da relação da natureza com a ação da sociedade e das culturas humanas. Sendo assim, ela é uma construção, também cultural e social. Apresentaremos o modelo ainda dominante de conservação, o chamado preservacionismo e, também, aquele modelo que entende a conservação da 
biodiversidade em consonância com sociedades tradicionais, o conservacionismo ou a ecologia social. É no ponto abordado acima que enfatizamos a necessidade de uma mudança no paradigma da proteção da biodiversidade. Não estamos descartando a necessidade da conservação ambiental, que é fundamental para a reprodução da vida humana, somente alertando para a maior vulnerabilidade das comunidades tradicionais, frente às transformações do mundo moderno.

PALAVRAS-CHAVE: Quilombos contemporâneos, proteção da biodiversidade, território.

RÉSUMÉ: Les quilombos étaient et sont des structures qui vont au-delà de votre caractéristique typique de la résistance, ces communautés sont des matérialisations de l'organisation sociale de l'Afrique qui a été formé dans les zones urbaines et rurales du Brésil. Un point important, la présence de personnes d'origine africaine au Brésil, concerne la relation entre les communautés quilombos avec l'environnement qui les entoure. La gestion des ressources naturelles dans le bassin versant de la communauté a toujours été une préoccupation des populations traditionnelles. En effet, la nécessité d'utiliser ces ressources de manière durable est un élément important dans le maintien et la reproduction de la communauté tout au long de leurs générations. Nous partageons le principe selon lequel la biodiversité, comme c'est actuellement réalisé, est le résultat de la relation de la nature et de l'action de la société et les cultures humaines. Ainsi, il s'agit d'une construction, aussi social et culturel. Présenter le modèle encore dominant de conservation, appelé préservationnisme et aussi ce modèle qui tient compte de la conservation de la biodiversité en ligne avec les sociétés traditionnelles, conservatisme ou l'écologie sociale. Il est le point ci-dessus fait que souligner la nécessité d'un changement de paradigme en matière de protection de la biodiversité. Nous n'excluons pas la nécessité de la conservation de l'environnement, ce qui est essentiel pour la reproduction de la vie humaine, ne avertissant de la vulnérabilité accrue des communautés traditionnelles, face aux transformations du monde moderne.

MOTS-CLÉS: quilombos contemporains, protection de la biodiversité, le territoire.

KEYWORDS: Contemporary quilombos, biodiversity protection, territory.

\section{INTRODUCTION}

Search what we call contemporary quilombola communities is, first of all, get in touch with ancestral energies. Quilombola territories of Brazil retain in greater or lesser intensity, important structures of what we recognize as a typical African Brazil. In this perspective, we assume that entering these territories requires respect and fundamentally understanding of their reality. 
Quilombos were and still are structures that go beyond their typical feature of resistance. These communities are materializations of African social organization that was formed in Brazil's urban and rural areas, with a peculiar territorial organization. Over the years, these contemporary quilombola territories engaged in all kinds of territorial conflict, because in many cases the process of recognizing and entitlement of their lands bumps into other interests. Within the main situations we can enumerate some conflicts involving contemporary quilombola communities and other groups or institutions, such as farmers, industries, and dams for hydroelectric power plants, military and security areas, protected areas, among others.

This article is part of research conducted in the Postgraduate Program in Geography of the University of Brasilia, which resulted in the elaboration of Master Dissertation $^{1}$ about a Case Study involving territorial overlap between Quilombola Community and Conservation Unit of Full Protection, in the Jequitinhonha Valley in Minas Gerais. Thus, the objective of this work is to present a theoretical and conceptual framework about the investigation of conflicts between Conservation Unit of Full Protection and Contemporary Quilombos, as well as their relation to the maintenance of biodiversity.

The motivations for the implementation of the researched problem originated in theoretical propositions and antagonistic ideologies, where the preservation of environmental resources realizes on the one hand, the importance of traditional populations as degradation factor and on the other, as agents of conservation of the environment. In this aspect, we entered into a complex theoretical and methodological scope, since the guarantee of the right to the territory of quilombola communities is as important as environmental preservation. We understand that in the elaboration of the legislative body and the formulation of politics related to preserving the environment, there is a tendency to marginalize the presence of these traditional populations in areas with potential for creating spaces for environmental protection. The result is inevitably the formation of a complex social conflict.

\footnotetext{
${ }^{1}$ VILELA, Rodrigo de Oliveira. Quilombos contemporâneos e a proteção da biodiversidade: o caso da Reserva Biológica da Mata Escura e da Comunidade Mumbuca. Vale do Jequitinhonha/MG . 2013. $163 \mathrm{f}$. Dissertação (mestrado) - Universidade de Brasília, Programa de Pós-Graduação em Geografia, 2013. Disponível em: http://hdl.handle.net/10482/14688
} 


\section{CONTEMPORARY QUILOMBO: TERRITORY TERRITORIALITY}

AND

By conducting studies related to traditional populations territorial analysis is fundamental, because understanding the territory and its meanings is important in the definition of the actors involved in the identity construction, the elucidation of conflicts and the representations of the quilombolas as a traditional community, since it is in the territory that these aspects are manifested.

It is in the territory that this way of life is established and in him which takes place self-identification, which is the main factor for characterizing a community as traditional. There is only the possibility of recognition of certain traditional practices where they are rooted in the population and manifested concretely in geographic space.

Thus, we believe that the territory definition proposed by Milton Santos can be applied to territorial realities of traditional communities. For Santos (2002, p. 96), "territory is the ground and the population, that is, an identity, the fact and a sense of belonging to that which belongs to us. Territory is the basis of work, residence, spiritual and material exchanges and life, upon which it influences."

Accordingly, we perceive that there is a concern of the author in rescuing the concrete presence of the territory, since social relations have become volatile and are modified in an accelerated manner. A fact that is not manifest in an exemplary way in traditional communities, which still retain their actions based on family relations of production and in domestic work, using relatively simple technology and the importance of myths and rituals associated with hunting, fishing and the extractive activities (DIEGUES, 2001).

The singular form of territory appropriation by the traditional communities creates an identity of this population. In this case, identity is guided in everyday working relationships in the land, in the traditional knowledge associated with the preparation of the planting, the collection of natural resources and the symbolism of the festivities and religious beliefs.

\footnotetext{
${ }^{2}$ All direct quotes were freely translated by the translator of this work, Cleison Leite Ferreira - Master in Geography at the University of Brasilia - UNB.
} 
The identity cited by Milton Santos is fundamentally territorial. It is a reality evidenced in everyday life and social relations of the community.

From this perspective, Marcos Saquet (2007) expresses well the relationship between the development of territoriality and everyday relationships asserting that

The economic, political and cultural, united and reciprocally related forces actualize the territory, the social process, in and with the geographic space, centered and originated in and of the everyday territoriality of individuals in different centralities, temporalities and territorialities. (SAQUET, 2007, p. 57).

Saquet also complements saying that "the social and natural processes, and even our thought, actualize themselves in and with everyday territoriality. It is there, at this level, that our life takes place and this is where the territoriality is realized." (op.cit).

We realize that both aforementioned authors consider the territory as a construction of everyday identity, work relations, the place of residence and where life manifests. What gives the uniqueness of a traditional community is precisely how this manifests its features in a given territory, linked to the notion of belonging, in the course of its life, resulting in the so-called everyday territoriality. (SANTOS; SAQUET, 2002, 2007).

Thus, in the enjoyment of territorial, material and symbolic resources, traditional communities draw a territoriality itself. The territory to exist empirically depends on the development of the territorialization process, that is, the appropriation of its resources by the population, as shown in the passages of Santos and Saquet discussed above.

In Brazil, the quilombo was and remains a territorial reality obfuscated of the formation of Brazilian society complex process, being marginalized and becoming invisible over the years. Brazil was a colony that received the largest number of African human beings as slaves, over the four centuries of the slave process and we agree with the idea that there was, throughout the formation of the Brazilian State, a forgetting of the presence of this population in the characterization of the Brazilian population. Furthermore, we understand that there is an urgent need for visibility of these communities in the Brazilian territory, as asserted by Anjos (2013):

The deliberate forgetfulness of communities and territories descendants of old quilombos, strategic geographic sites where mainly 
grouped people of African reference, as also Indians and Europeans excluded from society, who rebelled against the slave system of the time, forming free communities, self-sustaining and strong territorial organization, is one of emergency and structural issues of contemporary Brazilian society. It is inconceivable to conduct readings of our territory, of continental dimensions, without considering the geography of the quilombos and structured spaces, in the surviving "Colonial Brazil”. (ANJOS, 2013, p. 137).

We must understand that the quilombos are both those that formed in the colonial and imperial periods in Brazil, such as rural or urban black communities of contemporary Brazil. In both moments, the formation of the quilombo enlisted the help of the peculiarities of the Brazilian territory, beyond the significant amount of slave population, often exceeding the free population. The populations of the quilombos of yore and current quilombolas of Brazil have always had nature as an ally in the formation process of communities. Geographical conditions permitted the establishment and stability of the quilombo, hampering its identification (FIABANI, 2005).

The nature as an ally and the peculiar geographical conditions configure the quilombola site as closely linked with the natural resources territory. To illustrate these characteristics, we present in Figure 01, where we can view different quilombolas sites in some regions. It is important to understand how these populations have interacted with the environment to ensure its existence. 

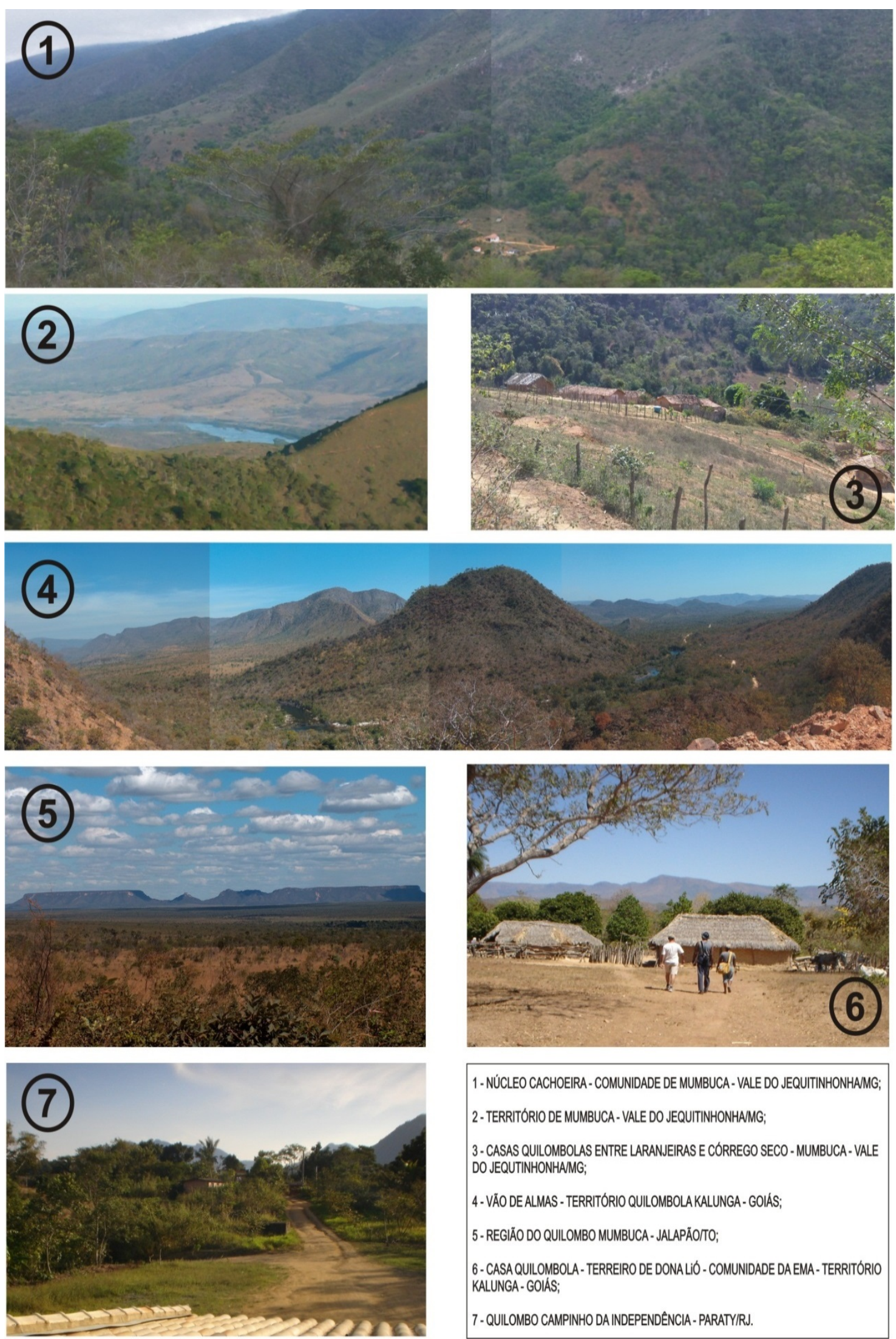

1- NÚCLEO CACHOEIRA- COMUNIDADE DE MUMBUCA-VALE DO JEQUITINHONHAMG; 2-TERRITORIO DE MUMBUCA-VALE DO JEQUITINHONHAIMG;

3- CASAS QULLOMBOLAS ENTRE LARANJEIRAS E CÓRREGO SECO - MUMBUCA-VALE DO JEQUTINHONHAMG;

4-VÃO DEALMAS - TERRITÓRIO QUILOMBOLA KALUNGA-GOIÁS;

5-REGIÄO DO QUILOMBO MUMBUCA - JALAPÃOITO;

6- CASA QUILOMBOLA- TERREIRO DE DONALLO - COMUNIDADE DA EMA- TERRITORIO KALUNGA-GOIAS:

7- QUILOMBO CAMPINHO DA INDEPENDÊNCIA- PARATYIRJ.

Figure 01 - Photographic records of quilombolas sites. Some Brazilian regions. Source: Photographs of the author. Fieldworks, 2006 - 2012 Elaboration of the author. 
The understanding of what today is the quilombo is diverse. Anjos (2009) extends the concept of quilombola communities, stating that they managed to "occupy land and maintain a political and economic independence and territorial identity.” The author also points out that "the contemporary quilombo must be associated with a broader interpretation, not only of resistance in the past, but especially in this" (ANJOS, 2009, p. 108).

Contemporary quilombos originated in various forms, such as the occupation of failed or abandoned farms; with the purchase of properties by freed slaves; donations of land by ranch owners or religious order; payment for services rendered in official wars; and extensions of land not properly registered by the Union (ANJOS, 2009).

The breadth of interpretation of what is contemporary quilombo derives precisely from its territorial processes, as well as the various forms of quilombola communities origin. Regardless of the process by which the community has passed which ensures the unit to these territories is its ethnic origin. This is how we can say that the various territorial processes manifested in quilombola communities led to a territorial identity based on a way of appropriation of the quilombos own territory.

We realize that territorial identities and the everyday aspects are important in identifying a traditional quilombola community. These are the constituents of everyday territoriality of quilombo: territory, the way of life and the quilombolas identity. The set of factors that give identity to a quilombola community and the use that it makes of the territory from its everyday practices builds the territoriality of the group, since it is in the territory that manifest its concrete actions (economic and political) and symbolic (beliefs and cultural events).

One of the most important characteristics of quilombola territory is in its location, since many of them have established their occupations in areas of difficult access, granting strategic feature to their locations. Therefore, the settlement pattern of the quilombola population is a basic reference for its maintenance and survival, always looking for the possibility of cultural, social and economic reproduction.

About this aspect Anjos and Cypriano (2006) indicated that the territorial organization of the quilombo depended on the strategic geographical location in areas of difficult access, but with the possibility of subsistence, where there would be the 
possibility of development of agriculture and use of hunting, fishing and collection. This whole situation gives the quilombola community, a great culture of space; land is collective and, above all, is sacred.

Anjos (2011) adds that the quilombo "is an ethnic territory, able to organize and reproduce in the geographical space of adverse conditions, over time and with resistance to maintain their peculiar way of living” (ANJOS, 2011, p. 18). The adversity and conflict are realities linked historically to the quilombo. Since its classical organization with the rejection of the slave condition until we recognize as contemporary quilombo, black population, organized in communities, developed territorial practices of resistance. The peculiarity of this way of life is also given by the physical conditions of the spaces occupied by quilombos. The presence of these populations in regions with restricted access, such as valleys, interior plateaus, stretches of forest, riverine areas or coastlines distant from urban centers, has given a need to own productive organization, since black community social organization remained marginalized from the dominant system.

\section{CONTEMPORARY QUILOMBO: MAINTAINING BIODIVERSITY AND TERRITORIAL RELATIONS.}

The quilombola territory, besides developing strategic aspects of its location, linked to the land resistance process, as seen above, has also created strategic relationships with the environment. For this reason, concern for biodiversity conservation in the quilombola territory is also a key factor in strategic occupation of these communities. The conservation of the natural aspects of the territory of the quilombo was and remains important for the maintenance of the group in its ancestor space.

Arruda (1999) indicates the following:

Most areas still preserved of the Brazilian territory are inhabited with varying density by indigenous peoples or "traditional" rural communities - native population, riparian, rubber, quilombolas, hicks for which the conservation of fauna and flora is guaranteed of its continuity. (ARRUDA, 1999, p. 90).

The way the community manages the natural resources contributed to the conservation of these elements, so it is important for both strategic location as to ensure the necessary resources for spatial reproduction of the quilombola population. Diegues 
(2000) states that the cultures and traditional knowledge can contribute to the maintenance of ecosystem biodiversity, since "this knowledge is the result of a coevolution between societies and their natural environments, which allowed the continuation of the balance between them" (DIEGUES, 2000, p. 18).

As seen, the quilombola territorial organization is materialized in its strategic occupation of space, that is, in the use of the territory by the community. We observed that the various characteristics of this occupation in areas of difficult access, resistance is a way to live, based on the logic of livelihood and biodiversity conservation. This whole plot sought over the years to attempt to ensure the continuity of the community, in many cases was successful, since we have the most varied examples of quilombolas communities, which have survived the centuries using the strategies discussed here.

We share the principle that biodiversity, as is currently realized, is a result of the relationship between nature and action of society and of human cultures. Thus, it is a construction, also cultural and social (DIEGUES, 1999).

Within this perspective, we start from the analysis of biodiversity, focusing on two pillars: One is the preservationism that is still a dominant model of conservation. And the other one, the conservationism or social ecology, that understands the conservation of biodiversity integrated with traditional societies.

The preservationist model, which emphasizes the idea of strictly protected areas, reinforces the view that biodiversity is not only a natural product. It proposes that conservation implies the absence and the removal of traditional populations inside (DIEGUES, 1999). Still regarding this subject the same author confirms that the issue of "prohibition on the presence of these communities in areas of indirect use even when it is a presence for several generations", this idea assumes that "every society-nature relationship is degrading and destructive of the natural and wild world" (DIEGUES, 1999 p.4).

This approached by the preservationist and ecologist perspective has theoretical support in the call Deep Ecology, "which, with a biocentric vision, says that nature should be preserved regardless of the contribution that can bring to humans" (DIEGUES, 1999, p. 5). 
On the other hand, according to Diegues (1999), theoreticians related to social and ecological conservatism noted that many areas inhabited by traditional populations had both forests and biodiversity conserved by the manipulator action linked to the way of life of these communities which still, with the creation of protected areas, were subject to expulsion.

Carril (2006) discusses, when addressing this issue, that the quilombo is associated with a "differentiated use of natural resources, and often, is the opposite of the use the dominant society undertakes to take ownership of these resources" (CARRIL, 2006 p. 8-9). The use of simple technologies and artisanal character of production capacity are associated with low environmental impact of traditional populations. As explained above, we believe the use that these communities make of the territory is also a conservative practice of the environment.

A symbiotic relationship with nature is by how resources are managed and also in a symbiotic relationship with the territory. There is no possibility of developing traditional life if we do not consider that there is a deep connection between the community and biodiversity, based on the importance of traditional knowledge in maintenance. We understand that there is the need to combine the presence of traditional communities and the importance of establishing protected areas for the maintenance of national biodiversity, but we question how these spaces were created, as well as the ideology that justified the deployment of Conservation Units in Brazil.

The protection model adopted in Brazil stems from a perspective used in the United States in the nineteenth century, culminating in the creation of Yellowstone, the first National Park of the World. The establishment of this park is the idealization of the wild world, contrary to the uncontrolled growth of urban-industrial spaces in the late nineteenth century, in the USA and Europe. Then, a need arises to rescue the picturesque world of what was left of "wild nature".

The appreciation of the natural world and the perspective that these spaces are considered "islands" of great beauty and aesthetic value that led humans to the contemplation of natural wonders, inserts the concept of national park as natural and wild area (DIEGUES, 2001). 
By absorbing these ideals of great ecological and cultural diversity, countries like Brazil have promoted deep conflicts when developing environmental public politics. Diegues (2001) emphasizes that this dichotomous reality between "people and parks” produced “devastating effect on traditional peoples, extractivist population, fishermen, indigenous people, whose relationship with nature is not different from the so-called traditional societies” (DIEGUES, 2001, p. 37).

Corroborating this fact, we understand that

Every establishment of a new protected area requires changes in relationships between social groups and such groups with the environment, in a two-way process in which environmental protection is socially constructed while influencing local populations and their relationships with wider society (COELHO; CUNHA; MONTEIRO, 2009, p. 69).

The advent of a Conservation Unit has a profound potential modifier in the life ways of populations living within or near the limit of the unit, since it regulates the way environmental resources should be managed, usually, in an unrelated logic to the communities involved. Conservation Units "when created and implemented, they influence and transform these practices in a changing, conflicting and complex configuration of social relations” (op. Cit.)

We must then assume that the space known as natural or wild is not something anomalous for traditional populations. It is actually their territory. Where they live, they can exercise their production processes, express their cultural and social structures. So the government when create a Conservation Unit of full protection, disregarding the diversity of population that inhabit that place, creates a deep conflict, since by law, these populations should be removed, preceded by payment of compensation. It is known that the process for implementation of those laws is slow and precedes a series of situations that often are not covered by the regulation.

Based on the importance of traditional knowledge in biodiversity conservation, we understand that there is a need to link the presence of traditional populations and the importance of creating the Conservation Units for the maintenance of national biodiversity. But we question how these spaces were created, as well as the ideology that justified the establishment of Units of Conservation in Brazil. 
The relationship between quilombola communities and the environment is important for a deeper understanding of the relationship between traditional communities and natural available resources in their territories. It then becomes important to know and understand the different practices of these groups that have managed over time, develop knowledge of ecosystems, based on the experience of relations with nature. What led to the adaptation to the ecological environment of high complexity, thanks to the knowledge accumulated over the territory and the different ways in which the work is done (CASTRO, 2000).

\section{FINAL CONSIDERATIONS}

Recognizing the importance of preserving natural resources by contemporary quilombola communities is a required exercise to deepen the understanding of the importance of this population matrix in Brazil. It is one more point to be incorporated and treated as a contribution of the African population in the composition of the Brazilian territory.

The territory of quilombo was the favorable space to the development of truly sustainable environmental practices. In these communities the importance of nature is essential for the maintenance and reproduction of the social group. In times of great environmental crisis, traditional communities have much to teach us about consistent management practices and biodiversity conservation.

The misunderstanding of these practices is derived directly from a forced invisibility that quilombolas communities crossed and currently cross, especially on issues involving the land regularization of quilombolas territories. When this situation involves the perspective of protecting biodiversity, linked to the implementation of Conservation Units, we realize that in many cases there are still inadequate and technicist conceptions regarding the presence of traditional populations (Arruda, 1999).

Our landscapes are still home to a wide variety of populations

of great sociocultural diversity that developed lifestyles related to specific natural environments, with their particular world views, extensive and thorough knowledge of natural processes and establishing relationships with the natural world different from those that prevail in urban-industrial societies (Arruda, 1999, page 86). 
We are not ignoring the need for environmental conservation, which is essential for the reproduction of human life. We are only calling attention to the increased vulnerability of traditional communities, face the transformations of the modern world. The government should have a duty to monitor and control environmental impacts, regardless of what kind of people or what is the way to use the land and its resources.

Quilombos, then, are doubly marginalized, first by being an excluded ethnic matrix for centuries and also by defining themselves as traditional communities. Against hegemonic interests, quilombos are configured as obstacles to development, since inhabiting areas liable to economic exploitation or restrictive environmental protection.

Another important factor in the invisibility of quilombolas communities was approached by Souza (2008). To explain about the disregard of the quilombo in the construction of national identity, the author states that this situation

expresses the historical silencing of non-hegemonic spaces in the country. Example is slowness in recognizing collective land occupied by the quilombolas communities, which are opposed to the model constructed as hegemonic that is based on private land (SOUZA, 2008, p. 77).

In many situations, the quilombola communities now have visibility only with the outbreak of the conflict. When self-define quilombolas they assume the possibility of ensuring the dominance of their land, triggering the clash of opposites titration planning groups which have private interests in the lands occupied by the quilombolas.

From the moment that takes place the motivation for a conflict of interests, often quilombola identity acquired by population is classified as doubtful or even fallacious, with clear motive to disrupt a legitimate political movement of that portion of the population. We understand that these situations of conflict, the quilombolas pass to be recognized and to leave a position of invisibility to a residual position in the landscape. That is, they are there and are now recognized, but not for its historical path of resistance and residence, but for obstructing interests of other groups.

Currently the situation of quilombola communities is weakened both by the spraying of public policies for these communities in various government agencies, such as the dismantling of quilombola weakened political movement that has no strength to 
work for their rights, so this research could contribute to some important themes for the Brazilian quilombola propositions and the protection of biodiversity, namely:

- Theoretical analysis of territoriality in contemporary quilombola communities, with regards to their ways of life and territorial appropriations;

- Search for an approximation of the concept of contemporary quilombo, competing against the various resemantizations the word quilombo assumed over the years and consolidate the importance of trying to establish a geographic term to characterize quilombo, emphasizing its territorial identities and the everyday aspects that are important in the identification of traditional quilombos;

- Contemporary quilombos are sacred spaces of reproduction of a significant portion of Afro-Brazilian population ways of life. These spaces have concrete references of social and territorial organization guided by profound notions of collectivity, of own cultural expressions and forms of symbiotic land uses with natural resources;

- The search for a gradual change of paradigms that guide the protection of biodiversity in Brazil, done from coherent principles with the reality of the country and its multifaceted cultural, social and geographical composition.

We understand that this problem is not limited to the considerations listed above. There is actually a need for further analysis involving the quilombos and their conflicts from the perspective of a typical Afro-Brazilian Geography, engaging with marginalized segments of the population.

\section{REFERÊNCIAS BIBLIOGRÁFICAS}

ANJOS, R. S. A. Quilombos - Geografia Africana - Cartografia Étnica Territórios Tradicionais. $1^{a}$ ed. Brasília: Mapas Editora e Consultoria, 2009. p.190.

Territorialidade quilombola - Fotos \& Mapas. Brasília: Mapas Editora e Consultoria, 2011. p.112.

A Territorialidade dos quilombos no Brasil contemporâneo - Uma aproximação. In:

SILVA, T. D.\& GOES, F. L. (orgs.) Igualdade racial no Brasil: Reflexões no ano internacional dos afrodescendentes, Brasília: IPEA, 2013, pp. 137 - 152. 
ANJOS, R.S.A. \& CYPRIANO, A. Quilombolas - tradições e cultura da resistência. Aori Comunicações. Petrobrás. São Paulo, 2006, p. 240.

ARRUDA, Rinaldo. "Populações Tradicionais” e a proteção dos recursosnaturais em unidades de conservação. In: Ambiente \& Sociedade - Ano II, n.5, p. 79-92, 1999.

CARRIL, L.F.B.Quilombo, Território e Geografia. AGRÁRIA, São Paulo, n.3, p. 156171, 2006.

CASTRO, Edna. Território, biodiversidade e saberes de populações tradicionais. In: DIEGUES, A. C. Etnoconservação. Novos rumos para a proteção da natureza nos trópicos. $2^{\text {a }}$ Ed. São Paulo: HUCITEC, 2000. p. 290.

COELHO, M. C. N, CUNHA L. H, MONTEIRO, M. A., "Unidades de Conservação: populações, recursos e territórios - abordagens da geografia e da ecologia política” In: GUERRA, Antonio José Teixeira; COELHO, Maria Célia Nunes. (Orgs.).Unidades de Conservação: abordagens e características geográficas. Rio de Janeiro: Bertrand Brasil, 2009. 296p.

DIEGUES, A. C. Biodiversidade e comunidades tradicionais no Brasil. NUPAUB/USP - PROBIO/MMA - CNPq, 1999. p. 189.

(org.). Os Saberes Tradicionais e a Biodiversidade no Brasil. Ministério do Meio Ambiente - Coordenadoria da Biodiversidade. NUPAUB, Universidade de São Paulo, 2000.

2001.p. 169.

O mito moderno da natureza intocada. $3^{\mathrm{a}}$ Ed. São Paulo: HUCITEC,

FIABANI, Adelmir. Mato, Palhoça e Pilão: o quilombo, da escravidão às comunidades remanescentes (1532-2004). São Paulo: Expressão Popular, 2005, p. 424.

SANTOS, Milton. Por uma outra globalização - do pensamento único à consciência universal. 9a Ed. São Paulo: Ed. Record, 2002. p.174.

SAQUET, Marcos Aurélio. As diferentes abordagens do território e a apreensão do movimento e da (i)materialidade. In: Revista Geosul, Florianópolis, v. 22, n. 43, p 5576, jan./jun. 2007.

SOUZA, Bárbara Oliveira. Aquilombar-se: Panorama Histórico, Identitário e Político do Movimento quilombola brasileiro. Dissertação de Mestrado em Antropologia Social da Universidade de Brasília. Orientador: Prof. Dr. José Jorge de Carvalho. Brasília, 2008, p. 204.

VILELA, Rodrigo de Oliveira. Quilombos Contemporâneos e a proteção da Biodiversidade: $O$ caso da Reserva biológica da Mata Escura e da Comunidade Mumbuca. Vale do Jequitinhonha/MG. Dissertação de Mestrado em Geografia Gestão Ambiental e Territorial do PPGEA da Universidade de Brasília. Orientador: Prof. Dr. Neio Lucio de Oliveira Campos. Brasília, 2013, p. 163 